\title{
Contrasting effects of sampling scale on insect herbivores distribution in response to canopy structure
}

\author{
Frederico S. Neves ${ }^{1 *}$, Carlos F. Sperber ${ }^{2}$, Ricardo I. Campos ${ }^{3}$ Janaína P. Soares ${ }^{4} \&$
}

Sérvio P. Ribeiro ${ }^{4}$

1. Laboratório de Ecologia de Insetos, Departamento de Biologia Geral, Universidade Federal de Minas Gerais, Belo Horizonte, MG, Brazil; fred.neves@gmail.com

2. Laboratório de Orthoptera, Departamento de Biologia Geral, Universidade Federal de Viçosa, 36570-000, Viçosa, MG, Brazil; sperberufv@gmail.com

3. Laboratório de Ecologia de Formigas, Departamento de Biologia Geral, Universidade Federal de Viçosa, 36570-000, Viçosa, MG, Brazil; ricardo.campos@ufv.br

4. Laboratory of Evolutionary Ecology of Canopy Insects and Natural succession, DEBIO-ICEB, Universidade Federal de Ouro Preto, Ouro Preto, MG, Brazil; spribeiro@iceb.ufop.br

* Corresponding author

Received 29-XI-2011. C Corrected 20-VII-2012. Accepted 20-VIII-2012.

\begin{abstract}
Species diversity of insect herbivores associated to canopy may vary local and geographically responding to distinct factors at different spatial scales. The aim of this study was to investigate how forest canopy structure affects insect herbivore species richness and abundance depending on feeding guilds' specificities. We tested the hypothesis that habitat structure affects insect herbivore species richness and abundance differently to sap-sucking and chewing herbivore guilds. Two spatial scales were evaluated: inside tree crowns (fine spatial scale) and canopy regions (coarse spatial scale). In three sampling sites we measured 120 tree crowns, grouped in five points with four contiguous tree crowns. Insects were sampled by beating method from each crown and data were summed up for analyzing each canopy region. In crowns (fine spatial scale) we measured habitat structure: trunk circumference, tree height, canopy depth, number of ramifications and maximum ramification level. In each point, defined as a canopy region (coarse spatial scale), we measured habitat structure using a vertical cylindrical transect: tree species richness, leaf area, sum of strata heights and maximum canopy height. A principal component analysis based on the measured variables for each spatial scale was run to estimate habitat structure parameters. To test the effects of habitat structure upon herbivores, different general linear models were adjusted using the first two principal components as explanatory variables. Sap-sucking insect species richness and all herbivore abundances increased with size of crown at fine spatial scale. On the other hand, chewer species richness and abundance increased with resource quantity at coarse scale. Feeding specialization, resources availability, and agility are discussed as ecological causes of the found pattern. Rev. Biol. Trop. 61 (1): 125-137. Epub 2013 March 01.
\end{abstract}

Key words: feeding guilds, insect distribution, habitat complexity, resources availability, spatial scales, tropical forest canopies.

Canopies of tropical forests comprise a variety of habitats and resources, which are greatly related to the world's insect biodiversity (Stork et al. 1997, Basset et al. 2003). Canopy is the main habitat for energy assimilation and primary productivity in forests (Lowman \& Nadkarni 1995, Lowan 2009) rich in resources and primary consumers (Basset et al. 2003).
Although it is amongst one of the most diverse habitats of Earth, it is also one of the least studied (Lowman \& Wittman 1996, Basset et al. 2003, Lowan 2009, Nadkarni et al. 2011).

In a forest canopy, insect herbivores use host tree crowns and leaves not only as feeding resource, but also as oviposition sites, shelter from abiotic variance in temperature 
and humidity, and as enemy-free space (Lawton 1983, Novotny et al. 2003, Ribeiro et al. 2005, Ribeiro \& Basset 2007, Ribeiro \& Borges 2010). By finding such requirements, insects may develop host plant species fidelity (Ribeiro et al. 2005, Ribeiro \& Borges 2010). However, there is nearly no study on canopy habitat effects that deals with the contrast between host tree traits, and emergent canopy proprieties (Ribeiro et al. 2005, Ribeiro \& Borges 2010, Ribeiro et al. 2011).

Species diversity of insect herbivores associated to canopy may vary local and geographically (Stork et al. 1997), responding to distinct factors at different spatial scales (Godfray \& Lawton 2001, Lewinsohn et al. 2005). Distinct feeding guild will respond differently to very local or to regional habitat scale within a forest ecosystem (Denno \& Perfect 1994, Ødegaard 2003).

On a more local, hereafter fine, scale, as within individual tree crowns, resource quality and availability, as well as microclimate oscillations could be more important for insect distribution, based on specific interactions (Hunter et al. 1997, Campos et al. 2006a). Hence, various plant traits might affect distribution of associated herbivores, such as chemical and physical defenses, plant tissues water/nutrient contents (Rossi \& Stiling 1998), phenological variation in growth rate, leaf, flower and fruit production (Rehill \& Schultz 2002), and plant architecture (Lawton 1983, Denno \& Roderick 1991, Alonso \& Herrera 1996, Espírito-Santo et al. 2007).

At the coarse spatial scale, i.e., canopy regions composed of a set of contiguous crowns, insect species may be affected by variance in chemical defenses (Coley \& Barone 1996), generalist predators (Ribeiro \& Borges 2010), spatial heterogeneity, meristematic activity, seasonal shortage and unpredictability of resources (Basset et al. 2001, Novotny et al. 2003, Ribeiro 2003, Ribeiro \& Basset 2007).

Tree species richness was suggested as an important factor which may affect herbivorous insect species richness and distribution in the canopy (Novotny et al. 2002, 2003, Sobek et al. 2009). However, Ribeiro \& Basset (2007) showed that canopy gall-forming diversity and density were related to a restricted number of host tree species. Herbivore feeding guilds may thus respond differently to the same habitat conditions due to, mainly, level of specialization and life history constraints (Denno \& Roderick 1991, Vehviläinen et al. 2007, Sobek et al. 2009).

The aim of this study was to investigate how forest canopy structure affects insect herbivore species richness and abundance depending on feeding guilds' specificities. We tested the hypothesis that sap-sucking and chewing herbivore species are affected by canopy structure in two distinct spatial scales: inside-tree crowns, fine scale, and among-tree crowns, or canopy region, hereafter, coarse scale.

\section{MATERIALS AND METHODS}

Study area: Samples were taken in three forest sites within the Rio Doce Park, the largest continuous preserved forest (35 974ha) in Minas Gerais State, Brazil $\left(19^{\circ} 48^{\prime} 18^{\prime \prime}\right.$ $19^{\circ} 29^{\prime} 24^{\prime \prime} \mathrm{S}$ and $\left.42^{\circ} 38^{\prime} 30^{\prime \prime}-42^{\circ} 28^{\prime} 18^{\prime \prime} \mathrm{W}\right)$ (Campos et al. 2006a). The Park is located within the domain of Atlantic Forest, one of the World's biodiversity hotspots, under urgent need of data to support conservation actions (Myers et al. 2000). Altitude varies from 230 to $515 \mathrm{~m}$; climate type is Aw (tropical hot semi-humid), with wet seasons from October to March and dry seasons from April to September (Gilhuis 1986). The predominant vegetation is semi-deciduous seasonal forest, with $20 \%$ to $50 \%$ deciduous trees (Veloso et al. 1991). For reasons still under study, this forest canopy tend to have a particularly poorer insect fauna than observed in canopies of wet and closed equatorial forests (Campos et al. 2006b, Ribeiro et al. 2008).

Sampling design: In order to take the majority of the variation presented in the canopy structure inside Rio Doce State Park, the samples were collected at three sites, at least $10 \mathrm{~km}$ apart from each other, in the same forest. 
In each one of these sites, samples of crowns and canopy regions were taken from locations composed of four trees (trunk diameter $\geq 5 \mathrm{~cm}$ ), hereafter called canopy groups. In each canopy group, which were at least $50 \mathrm{~m}$ far apart, traits of these adjacent tree crowns were measured and insects sampled by beating in each crown. A total of 120 trees (fine spatial scale) in 30 canopy groups (coarse spatial scale) were sampled comprising the three sites. For the analysis, we considered the information from the three sampled sites as a whole total population, since we did not aim to compare inside Rio Doce State Park.

Canopy access and insect sampling: The canopy was reached with single rope climbing technique (Lowman \& Wittman 1996, Ribeiro \& Basset 2007, Lowman 2009, Neves et al. 2010). The insects were sampled only once in each tree, along 15 days in February 2004, which corresponds to the beginning of the rainy season, in warm, not raining days (between 9:00 - 16:00). Each insect sample unit consisted of one unique set per tree of vigorous beatings on the tree branche foliages all over, with 10 subsequent beats in each tree, so that the insects felt into a modified entomological umbrella (Ribeiro et al. 2005, Neves et al. 2010). Although this is a snapshot of the tree's insect fauna, we blocked the tree replicates within the canopy aiming to properly sample distinct sets of a same canopy location in a same time, and thus avoid one-place sample bias.

At the fine spatial scale, free-living insect herbivores species richness was estimated by counting the number of morphospecies (taxonomic operational units), while abundance was estimated by counting the accumulated number of individuals (see below). At coarse spatial scale, species richness was estimated by counting the accumulated number of morphospecies in the four tree crowns of each one of the 30 canopy groups, and abundance by the average number of individuals per tree-crown, from each canopy region. The immature insects sampled were only used in the analysis of abundance, not entered in richness analyzes.
Habitat structure at fine spatial scale: In each one of the sampled tree $(n=120)$, five architectonic parameters were measured (Fig. 1): (i) total tree height; (ii) crown depth, from the top of the crown to the first ramification; (iii) trunk diameter breast height (DBH); (iv) number of primary and secondary branches and (v) maximum ramification level (mean number of times that a branch divided into two branches with smaller diameter, see Fig. 1), estimated as the mean value out of three independent sequences of ramifications in a same tree.

\section{Habitat structure at coarse spatial scale:}

In each one of the canopy group $(n=30)$, the habitat structure was measured within a cylindrical volumetric space of one meter in diameter, according to the canopy pin-cylinder transect method (Ribeiro \& Basset 2007, Ribeiro et al. 2011). From three meters above the ground up to the upper canopy (Fig. 2), the following parameters were measured: (i) maximum canopy height; (ii) number of canopy strata (number of discontinuous foliage columns intercepted by the canopy pin-cylinder transect); (iii) sum of strata heights (the sum of discontinuous foliage column heights, intercepted by the canopy pin-cylinder transect); (iv) tree species richness (number of tree species intercepted by the canopy pin-cylinder transect); and (v) total leaf area (the sum of the estimated leaf area intercepted by the vertical transect). For the latter, the number of leaves intercepted by the vertical transect was counted for each individual tree at each stratum (Fig. 2: e1, e2 and e3). Then, one branch with at least five leaves was taken from each intercepted tree individual and the leaf area $\left(\mathrm{mm}^{2}\right)$ of three leaves, collected from different node levels was measured, using a digital scanning and the software Image J® (Rasband 2006). Finally, the mean leaf area for that tree stratum was calculated and multiplied by the number of leaves within the volumetric space of the canopy pin-cylinder transects. Hence, "total leaf area" was the sum of averaged leaf area for all strata leaves in each canopy pin-cylinder transect (Ribeiro et al. 2011). 


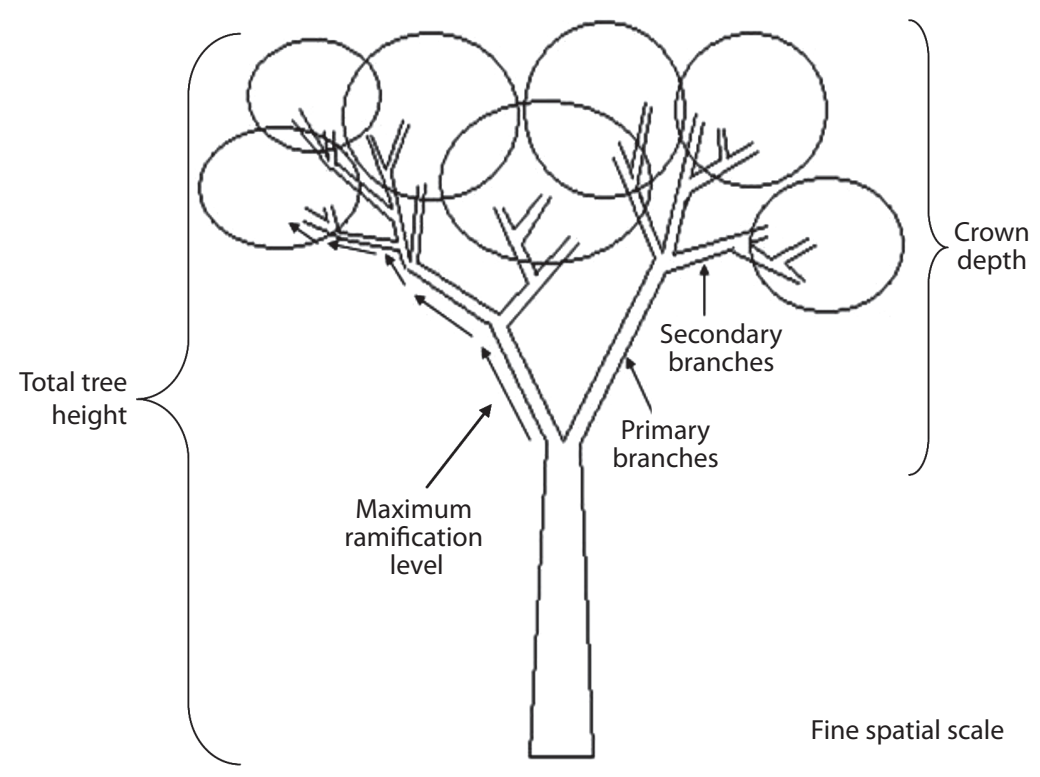

Fig. 1. Habitat structure parameters measured at the fine spatial scale.

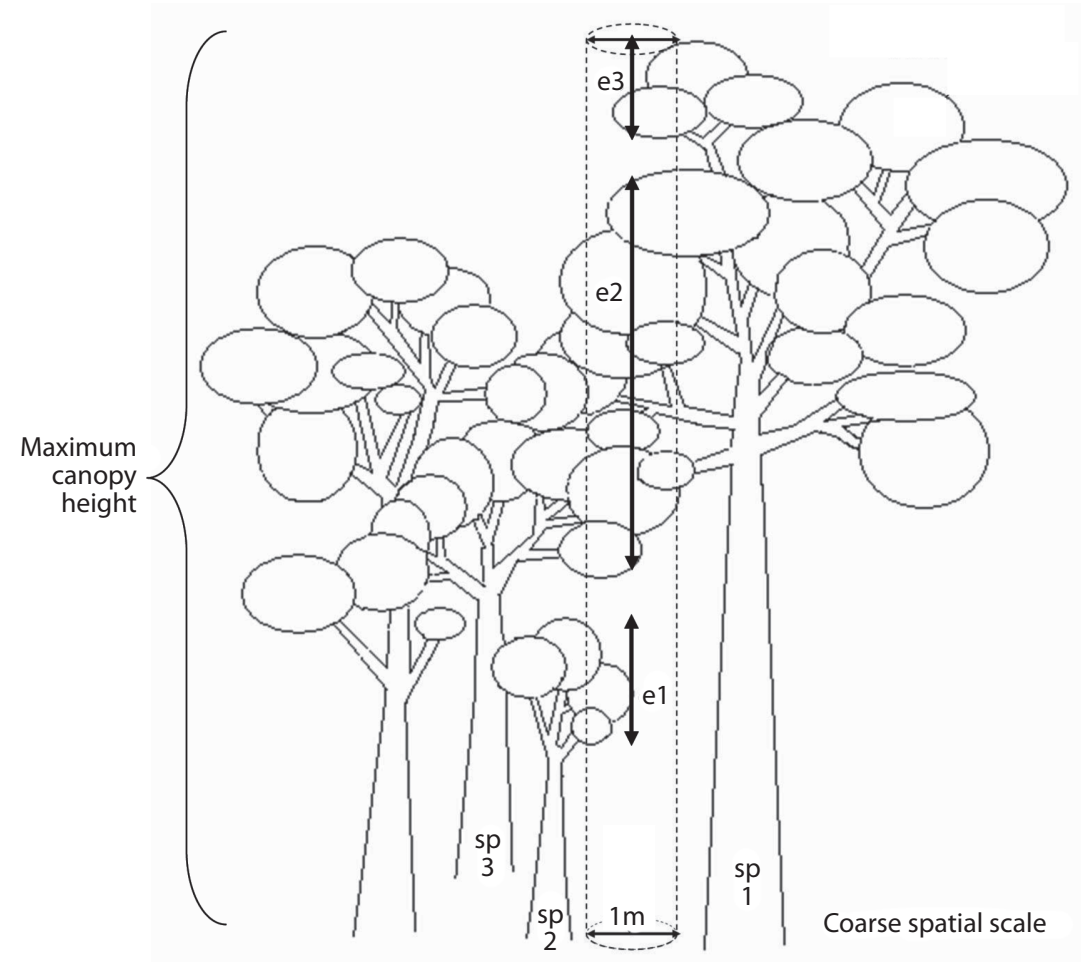

Fig. 2. Habitat structure parameters at the coarse spatial scale, illustrating the vertical pin-cylinder transect: sp1, sp2, sp3: different tree species intercepted by the vertical pin-cylinder transect; e1, e2, e3: different canopy strata. 
Herbivore guilds: The sampled insect herbivores were grouped in two feeding guilds: sap-sucking and chewing herbivores (Moran \& Southwood 1982). The herbivores were identified at family level using taxonomic keys (Borror et al. 2002), and comparison with specimens of the entomological collections of the Laboratory of Evolutionary Ecology of Canopy Insects and Natural Succession, in the Federal University of Ouro Preto (UFOP), Ouro Preto, $\mathrm{MG}$, and the Museum of Entomology of the Universidade Federal de Viçosa, Viçosa, MG. After identification at family or sub-family level, herbivores were separated into morphospecies, using external morphological characters. All collected insects were deposited at the entomological collections of the Laboratory of Evolutionary Ecology of Canopy Insects and Natural Succession, in the Federal University of Ouro Preto (UFOP).

The data were analyzed by the Principal component analyses (PCA) based on the measured habitat structure variables for each spatial scale were run to estimate habitat structure parameters. Such approach reduced habitat parameters into principal components, which were then used as explanatory variables. The use of PCA components was opted instead of the raw data because the measured parameters on both spatial scales were not orthogonal, the parameters were not independent, and thus the use of multiple regressions would not be recommendable (Manly 2005). Similar analyses were used in studies on the effects of leaf characteristics (Peeters 2002) and plant architecture (Espírito-Santo et al. 2007) on insect herbivores.

To test the effects of habitat structure upon herbivores, different general linear models analogous to multiple regressions were adjusted (Crawley 2002). The two principal components calculated for each spatial scale were used as explanatory variables for sap-sucking and chewing herbivores species richness and abundance, separately. Complete models included the two most important principal components axes at each spatial scale as explanatory variables. Significance was accessed by deletion of non-significant terms from the complete model (Crawley 2002). The adequacies of model and of error structure were evaluated by residual analysis.

\section{RESULTS}

As expected, data showed a particularly insect poor canopy, samples were composed by 339 insect herbivores belonging to 159 morphospecies. Overall, 58 morphospecies of sap-sucking insects were sampled, out of 80 individuals. Psyllidae was the most abundant taxa, with 12 individuals, divided in eight morphospecies. Chewing composed the richest and most abundant guild, with 101 morphospecies and 259 individuals, from which 36 morphospecies and 79 individuals belonged to Curculionidae, the most abundant taxa (Table 1).

Habitat structure effects at fine spatial scale: A total of $49 \%$ of variance in the tree crowns architecture were explained by the first axis of the principal component analysis of habitat structure at fine spatial scale, which was positively correlated to trunk diameter, tree height, canopy depth and maximum ramification level, and negatively correlated to the number of branch ramifications (Table 2). The second principal component analysis' axis explained $27 \%$ of variance and was positively correlated to the number of branch ramifications, presenting weaker positive correlation with the remaining habitat variables (Table 2).

Sap-sucking insect species richness and abundance increased in response to the first principal component of habitat structure at fine spatial scale (Fig. 3), as well as chewing abundance (Fig. 4). There was no significant variation of chewing species richness explained by this habitat variable. The second axis of habitat structure did not explain any variation in herbivore abundance or richness (Table 3 ).

Habitat structure effects at coarse spatial scale: A total of $54 \%$ of variance in canopy traits were explained by the first axis of the principal component analysis of habitat 
TABLE 1

Number of morphospecies (richness) and individuals (abundance) of herbivorous insects collected in the canopy groups in the Rio Doce State Park, Minas Gerais, Brazil

\begin{tabular}{|c|c|c|}
\hline Taxa & Richness & Abundance \\
\hline \multicolumn{3}{|l|}{ Sternorrhyncha } \\
\hline Psyllidae & 8 & 12 \\
\hline \multicolumn{3}{|l|}{ Auchenorrhyncha } \\
\hline Achilidae & 1 & 2 \\
\hline Cicadellidae & 6 & 10 \\
\hline Cixiidae & 1 & 1 \\
\hline Derbidae & 1 & 1 \\
\hline Flatidae & 3 & 3 \\
\hline Membracidae & 3 & 3 \\
\hline Tropiduchidae & 1 & 1 \\
\hline undentified nymphs & 17 & 23 \\
\hline \multicolumn{3}{|l|}{ Heteroptera } \\
\hline Coreidae & 1 & 1 \\
\hline Lygaeidae & 2 & 2 \\
\hline Miridae & 4 & 7 \\
\hline Pentatomidae & 1 & 2 \\
\hline Phloeidae & 1 & 2 \\
\hline Tingidae & 2 & 4 \\
\hline undentified nymphs & 6 & 6 \\
\hline \multicolumn{3}{|l|}{ Coleoptera } \\
\hline Aderidae & 1 & 2 \\
\hline Anobiidae & 3 & 12 \\
\hline Brenthidae & 4 & 23 \\
\hline Bostrichidae & 1 & 2 \\
\hline Buprestidae & 1 & 1 \\
\hline Cerambycidae & 1 & 1 \\
\hline Chrysomelidae & 15 & 61 \\
\hline Curculionidae & 36 & 79 \\
\hline Elateridae & 3 & 4 \\
\hline Lathridiidae & 1 & 1 \\
\hline Lycidae & 2 & 2 \\
\hline Mordellidae & 1 & 1 \\
\hline Phalacridae & 4 & 5 \\
\hline Scarabaeidae & 1 & 1 \\
\hline Tenebrionidae & 5 & 16 \\
\hline \multicolumn{3}{|l|}{ Phasmatodea } \\
\hline Phasmidae & 2 & 3 \\
\hline \multicolumn{3}{|l|}{ Lepidoptera } \\
\hline undentified larvae & 10 & 25 \\
\hline \multicolumn{3}{|l|}{ Orthoptera } \\
\hline Tettigonidae & 2 & 3 \\
\hline Acrididae & 8 & 17 \\
\hline Total & 159 & 339 \\
\hline
\end{tabular}

TABLE 2

Habitat structure at fine spatial scale: Correlation of the tree architectonic parameters, based on calculated principal components of the PCA

\begin{tabular}{lcc}
\multicolumn{1}{c}{ Parameters } & \multicolumn{2}{c}{ Component } \\
Total tree height & 1 & 2 \\
Crown depth & 0.86 & 0.30 \\
Trunk diameter & 0.77 & 0.31 \\
Number of primary branches & 0.87 & 0.22 \\
Number of secondary branches & -0.43 & 0.84 \\
Maximum ramification level & -0.45 & 0.83 \\
Variation explained & 0.67 & 0.06 \\
\hline
\end{tabular}

structure at coarse spatial scale, which was positively correlated to all habitat variables, especially tree species richness, sum of strata heights and maximum canopy height (Table 4). The second axis of the analysis explained 25\% of variance in canopy traits, and was positively correlated to available leaf area, number of canopy strata and, weekly, to tree species richness, and was negatively correlated to maximum canopy height and sum of strata heights.

Herbivore species richness and abundance were not explained by the first axis of the principal component at this scale (Table 5). On the other hand, chewers species richness and abundance increased with the second axis of this principal component analysis (Table 5, Fig. 5). Neither species richness or abundance of sap-sucking insects were affected by habitat structure at coarse spatial scale.

\section{DISCUSSION}

The density of herbivores found in the canopy of Rio Doce was noticeably low in this work (less than four individuals per tree crown beat, in average), coinciding with previous works in the same area (Campos et al. 2006b, Ribeiro et al. 2008). This number is contrastingly low when compared with closed, wet tropical rainforests sampled by the same method (Basset et al. 2001, Ødegaard 2003), and is similar to temperate insular canopy 
TABLE 3

Multiple regression analyses (using general linear models) of species richness and abundance of herbivores (response variable) against the principal components calculated by PCA at the fine spatial scale of habitat structure (explanatory variables)

\begin{tabular}{|c|c|c|c|c|c|c|c|c|c|c|}
\hline \multirow{4}{*}{ Source } & \multirow[b]{4}{*}{ d.f. } & \multirow[b]{4}{*}{ Residual d.f. } & \multicolumn{8}{|c|}{ Response variable } \\
\hline & & & \multicolumn{4}{|c|}{ Sap-sucking insects } & \multicolumn{4}{|c|}{ Chewing insects } \\
\hline & & & \multicolumn{2}{|c|}{ Species richness } & \multicolumn{2}{|c|}{ Abundance } & \multicolumn{2}{|c|}{ Species richness } & \multicolumn{2}{|c|}{ Abundance } \\
\hline & & & $\mathrm{F}$ & $\mathrm{p}$ & $\mathrm{F}$ & $\mathrm{p}$ & $\mathrm{F}$ & $\mathrm{p}$ & $\mathrm{F}$ & $\mathrm{p}$ \\
\hline Null model & & 119 & & & & & & & & \\
\hline Component 1 & 1 & 118 & 4.652 & 0.031 & 9.412 & 0.002 & 1.265 & 0.261 & 12.082 & $<0.001$ \\
\hline Component 2 & 1 & 117 & 0.189 & 0.664 & 0.041 & 0.840 & 0.279 & 0.597 & 1.238 & 0.266 \\
\hline Error distribution & & & \multicolumn{2}{|c|}{ poisson } & \multicolumn{2}{|c|}{ normal } & \multicolumn{2}{|c|}{ poisson } & \multicolumn{2}{|c|}{ normal } \\
\hline
\end{tabular}
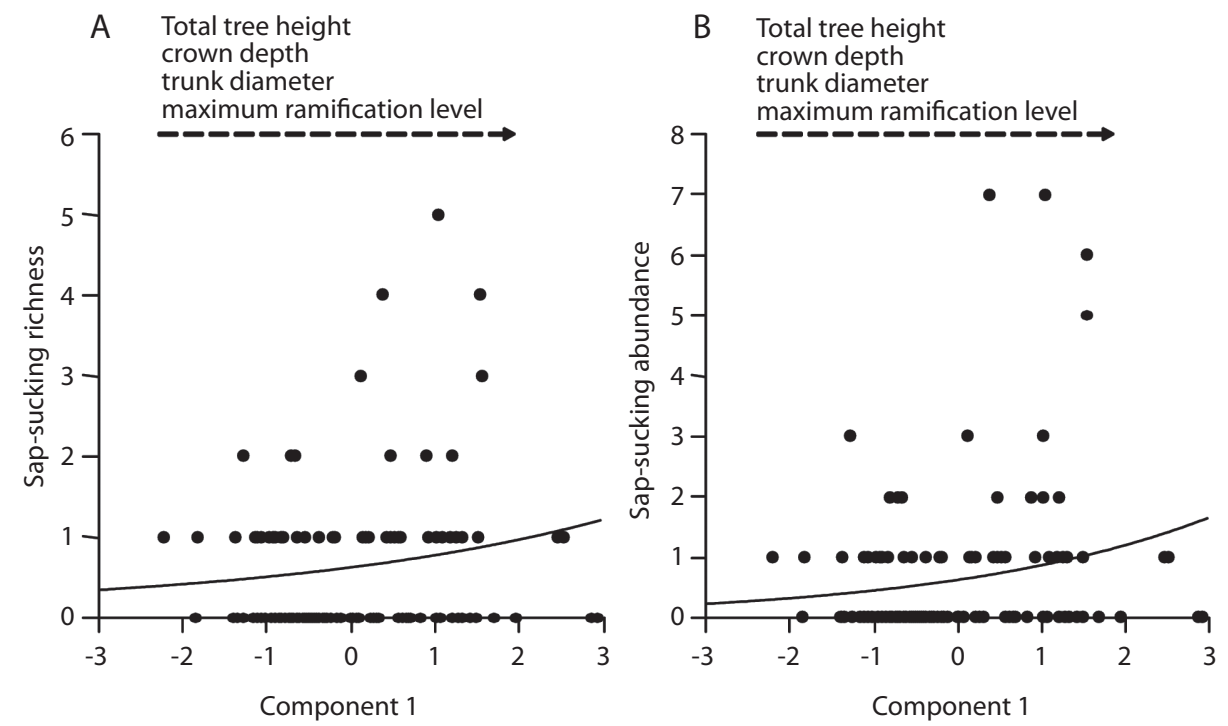

Fig. 3. Number of herbivorous sap-sucking insect morphospecies (a) and individuals (b) against the values for the first principal component calculated for habitat structure at fine spatial scale. Curves estimated adjusting by general linear model, with poisson error distribution $(\mathrm{p}<0.05$, table 3$)$.

forests studied (Ribeiro et al. 2005). Rio Doce river basin may be covered with a particularly insect species-poor forest due to its ecological young age. Geological studies suggest the whole region was broadly covered by xeric ecosystems and tropical dry forests no later than 4000 years ago during the Holocene (Overloop 1981, Werneck et al. 2011), which contributed to the origin of the lakes that define enormously this landscape (Pflug 1969,
Meis \& Monteiro 1979, Meis \& Tundisi 1986, Perônico \& Castro 2008).

Still, regardless fast and recent climatic and, consequently, ecological shifting, the relative abundance of herbivore taxa followed expected trends found in some Neotropical canopies (Ribeiro 2003). Psyllidae sap-sucking species and Curculionidae leaf chewing species dominated the present samples, and are also recurrently important components of 
TABLE 5

Multiple regression analyses (using general linear models) of the species richness and abundance of herbivores (response variable) against the principal components calculated by PCA at the coarse spatial scale of habitat structure (explanatory variables)

\begin{tabular}{|c|c|c|c|c|c|c|c|c|c|c|}
\hline \multirow{4}{*}{ Source } & \multirow[b]{4}{*}{ d.f. } & \multirow[b]{4}{*}{ Residual d.f. } & \multicolumn{8}{|c|}{ Response variable } \\
\hline & & & \multicolumn{4}{|c|}{ Sap-sucking insects } & \multicolumn{4}{|c|}{ Chewing insects } \\
\hline & & & \multicolumn{2}{|c|}{ Species richness } & \multicolumn{2}{|c|}{ Abundance } & \multicolumn{2}{|c|}{ Species richness } & \multicolumn{2}{|c|}{ Abundance } \\
\hline & & & $\mathrm{F}$ & $\mathrm{p}$ & $\mathrm{F}$ & $\mathrm{p}$ & $\mathrm{F}$ & $\mathrm{p}$ & $\mathrm{F}$ & $\mathrm{p}$ \\
\hline Null model & & 29 & & & & & & & & \\
\hline Component 1 & 1 & 28 & 1.223 & 0.267 & 0.472 & 0.498 & 0.679 & 0.410 & 1.309 & 0.263 \\
\hline Component 2 & 1 & 27 & 1.064 & 0.302 & 0.303 & 0.587 & 3.935 & 0.047 & 8.747 & 0.006 \\
\hline Error distribution & & & \multicolumn{2}{|c|}{ poisson } & \multicolumn{2}{|c|}{ normal } & \multicolumn{2}{|c|}{ poisson } & \multicolumn{2}{|c|}{ normal } \\
\hline
\end{tabular}

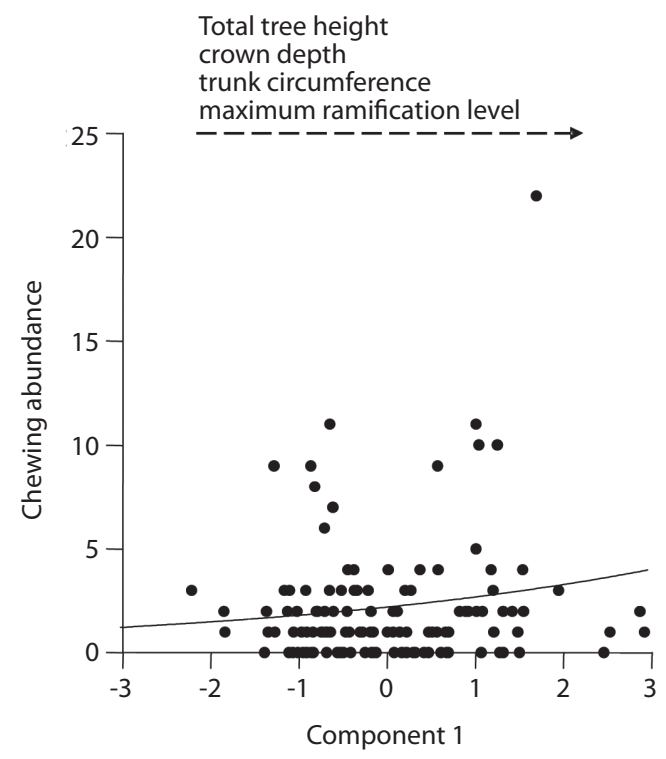

Fig. 4. Number of herbivorous chewing individuals against the values for the first principal component calculated for habitat structure at fine spatial scale. Curve estimated adjusting by general linear model, with poisson error distribution $(\mathrm{p}<0.05$, table 3$)$.

other tropical forest canopy insect communities (Kitching et al. 1997, Basset et al. 2001). In Panama, Chrysomelidae and Curculionidae were the dominant insects (Basset et al. 2001), likewise in the present work. Mostly important, the present data allowed us to investigate an important effect of habitat structure on herbivore species guilds.

\section{TABLE 4}

Habitat structure at coarse spatial scale: Correlation of the canopy-region parameters based on calculated principal components of the PCA

\begin{tabular}{lcc}
\multicolumn{1}{c}{ Parameters } & \multicolumn{2}{c}{ Component } \\
& 1 & 2 \\
Maximum canopy height & 0.79 & -0.52 \\
Number of canopy strata & 0.63 & 0.60 \\
Sum of strata heights & 0.80 & -0.49 \\
Tree species richness & 0.87 & 0.13 \\
Total leaf area & 0.51 & 0.61 \\
Variation explained & 53.68 & 25.33 \\
\hline
\end{tabular}

Habitat structure effects at fine spatial scale: This may be one of the first attempts to associate herbivore guilds to canopy habitat structure at distinct spatial scales. The habitat structure at fine scale was strongly defined by the tree crowns sizes (a combination of tree height, crown depth and trunk circumference), while the tree crown complexity (number of ramifications and level of ramifications(McCoy \& Bell 1991) composed a complementary environmental dimension, then statistically described by the first and the second axes of the principal component analysis, respectively.

Both sap-sucking and chewing herbivore abundances increased with tree crown size. This may result from a positive correlation between resource availability, crown size and herbivore population sizes, regardless of tree species and other traits. Several other studies 

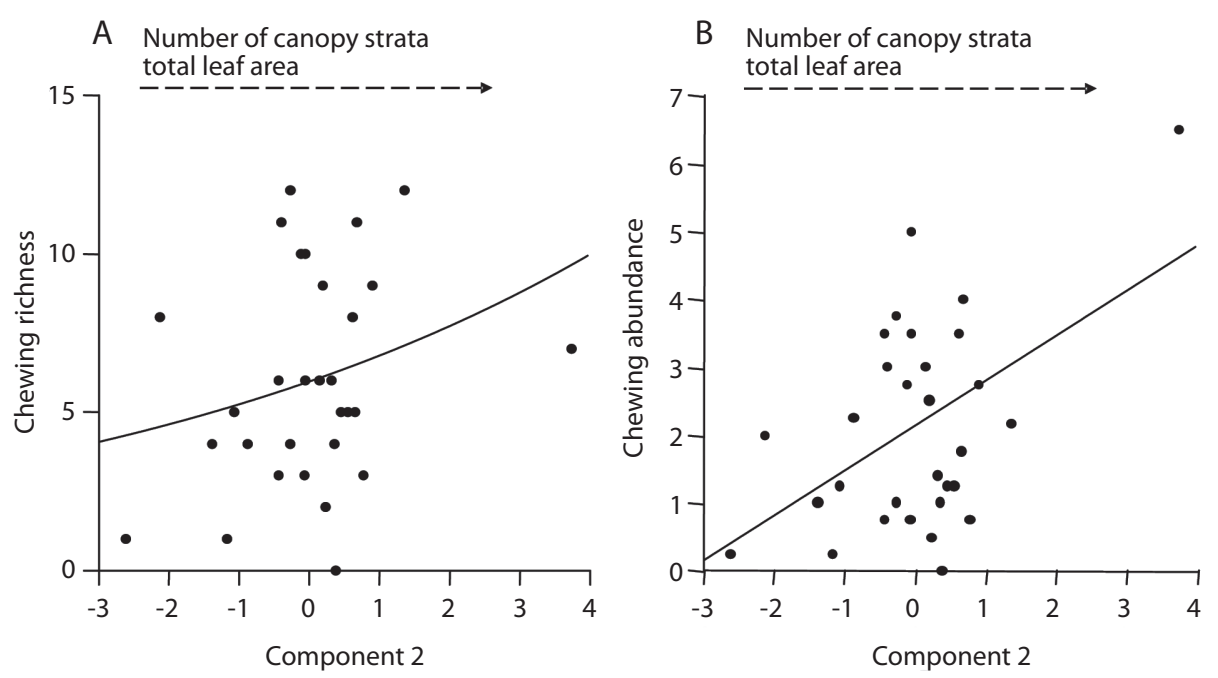

Fig. 5. Number of herbivorous chewing morphospecies (a) and individuals (b) against the values for the second principal component calculated for habitat structure parameters at the coarse spatial scale. Curves estimated adjusting by general linear model, with poisson error distribution $(\mathrm{p}<0.05$, table 5).

on tropical forests found greater herbivore species richness and abundance in mature trees, namely on the largest trees in the canopy (Basset et al. 2001, Campos et al. 2006a, Costa et al. 2011), or on tree species occupying the largest relative canopy area (Ribeiro et al. 2005, Ribeiro \& Borges 2010).

Herbivores in a host plant with large size have reduced costs of locomotion (Alonso \& Herrera 1996), as well as risk of attack from natural enemies (Bernays 1997, Rijhimäki et al. 2006, Ribeiro \& Borges 2010). Monophagous herbivores, as several sap-sucking species (Denno \& Perfect 1994), may also benefit from large host plants due to increasing feeding resource availability (Stiling \& Moon 2005).

Likewise, the species richness of sap-sucking herbivores was affected by canopy habitat structure at fine scale, i.e. increasing with crown size and decreasing with crown complexity. This may result from higher local resource availability, as proposed by the resource concentration hypothesis (Root 1973). The relation is, however, opposite to the expected response to habitat complexity. Complex habitats (sensu
Bell et al. 1991) are expected to harbor more species because of higher resource partitioning (Lewinsohn et al. 2005). Several studies detected higher insect species richness on host plants with more complex architecture (Lawton 1983, Denno \& Roderick 1991, Denno 1994, Heisswolf et al. 2005), but most of these studies did not distinguish between architectural complexity and host plant size.

Hence, the present study corroborates the resource concentration hypothesis to the detriment of habitat complexity hypothesis. The lack of significance of the regression between species richness and the second axis of the principal component, positively correlated to complexity, reinforces our conclusions.

Habitat structure effects at coarse spatial scale: The first axis of the principal component analysis on the coarse spatial scale was interpreted as a measure of resource availability in the canopy region, while the second axis was a measure of resource density, as it was positively correlated to variables related to resource quantity (number of canopy strata 
and total leaf area), but negatively to variables related to canopy volume (maximum canopy height and sum of strata heights).

Both chewing herbivore species richness and abundance were positively correlated with the increasing of relative leaf density, but not to tree species richness. Barrios (2003) showed that species richness and abundance of chewing herbivores increased with availability of young leaves in adult trees. Likewise, species richness of polyphagous beetles increases with the availability of young leaves (Basset 2001, Ødegaard 2003). The positive correlation of chewing herbivore richness and abundance with leaf density at coarse spatial scale in the present study may be a product of similar mechanism.

Canopy regions with highest leaf densities were also probably those where there was higher light incidence, leading to higher meristematic activity (Sterck et al. 2001, Barrios 2003, Ribeiro et al. 2011). In the present protocol, insect samples were taken from the peripheral regions of the tree crowns, in more external branches, coinciding with those places where crown expansion was likely to occur (Hallé et al. 1978, Lowman \& Wittman 1996, Bell et al. 1999, Sterck et al. 2001). The lack of a specific response from chewing herbivores to tree host species and crown units, suggest that a set of crowns producing greater amounts of resources should be the main attractive for this guilds, thus likely composed of generalists, as normally found in the canopies (Novotny et al. 2002, Ribeiro et al. 2005).

Different herbivore feeding guilds are affected at differing spatial scales in the forest canopy. Here we hypothesize that sap-sucking herbivores are strongly dependent on intrinsic characteristics of their host (Lawton 1983, Bernays \& Chapman 1994, Denno \& Perfect 1994, Novotny et al. 2003) at small spatial scale, rather than on surrounding canopy traits, probably because sap-sucking insects tend to be more specialized than leaf chewers (see Denno \& Perfect 1994, Ødegaard 2003). Conversely, chewers may respond to resource availability at a larger spatial scale as a matter of food and oviposition site diversification (Novotny et al. 2002), since such guild tend to be composed by generalists or oligophagous species (Basset 2001, Novotny et al. 2002, Ødegaard 2003). These findings further underline both the importance of spatial scale when analyzing insect herbivore diversity, but also the contrasting effect of sampling scale on different herbivore feeding guilds. Based on this we suggest that future studies on insect diversity, especially in the canopy, take multi-scale sampling at consideration.

\section{ACKNOWLEGMENTS}

We thank Tatiana Cornelissen, Patrícia A. Moreira and Marina Beirão for useful comments in previous drafts of this manuscript. This project was partially funded by the PROFIX/CNPq (\# 54552-01-1). Climbing gears were donated by British Embassy/FCO, Brazil, and students were trained by the Canopy Training course run by a consortium between, Global Canopy Programme and /UFOP. SPR is funded by the CNPq project \# pq 312241/20062. IEF kindly offered accommodation and two field climbers in support for this project. C.F.S. has a CNPq grant and F.S.N. and R.I.C. have a FAPEMIG grant.

\section{RESUMEN}

La diversidad de especies de insectos herbívoros asociados con el dosel puede variar geográficamente y responder a distintos factores a diferentes escalas espaciales. El objetivo de este estudio fue investigar cómo la estructura del dosel afecta la riqueza de especies de insectos herbívoros y la abundancia en función la especialización alimenticia. Se evaluó la hipótesis que propone que la estructura del hábitat afecta en forma diferente la riqueza y abundancia de especies de insectos que se alimentan de savia y la de especies herbívoras masticadoras. Dos escalas espaciales fueron evaluadas: el interior de las copas de árboles (escala fina) y regiones del dosel (escala gruesa). En tres sitios de muestreo medimos 120 copas de árboles, agrupadas en cinco puntos con cuatro copas de árboles contiguas. Los insectos fueron muestreados golpeando las copas y los datos fueron sumados para analizar cada región del dosel. En las copas (escala espacial fina) medimos la estructura del hábitat: circunferencia del tronco, altura del árbol, profundidad del dosel, número de ramificaciones y máximo nivel de ramificación. En cada punto, definiendo 
una región del dosel (escala gruesa), medimos la estructura del hábitat usando un transecto cilíndrico vertical: riqueza de especies árboles, área foliar, sumatoria de altura de los estratos y máxima altura del dosel. Fue realizado un análisis de componentes principales basado en las variables medidas para cada escala espacial para estimar los parámetros de la estructura del hábitat. Para probar los efectos de la estructura del hábitat sobre los herbívoros, se ajustaron diferentes modelos lineares generales usando estos componentes principales como variables causales. La riqueza de especies chupadoras de savia y la abundancia de todas las especies herbívoras se incrementaron con el tamaño de la copa en la escala espacial final. Por otro lado, la riqueza y abundancia de especies masticadoras incrementaron con la complejidad de la estructura del hábitat en la escala más gruesa. La especialización alimenticia, la disponibilidad de recursos y la movilidad son propuestas como los factores ecológicos que explican los patrones observados.

Palabras clave: gremios alimenticios, distribución de insectos, complejidad del hábitat, disponibilidad de recursos, dosel del bosque tropical.

\section{REFERENCES}

Alonso, C. \& C.M. Herrera. 1996. Variation in herbivory within and among plants of Daphne laureola (Thymelaeaceae): correlation with plant size and architecture. J. Ecol. 84: 495-502.

Barrios, H. 2003. Insect herbivores feeding on conspecific seedlings and trees, p. 282-290. In Y. Basset, V. Novotny, S. Miller \& R. Kitching (eds.). Arthropods of tropical forests: spatio-temporal dynamics and resource use in the canopy. Cambridge University, Cambridge, United Kingdom.

Basset, Y. 2001. Communities of insect herbivores foraging on saplings versus mature trees of Pourouma bicolor (Cecropiaceae) in Panama. Oecologia 129: 253-260.

Basset, Y., H.P. Aberlenc, H. Barrios, G. Curletti, J.M. Béranger, J.P. Vesco, P. Causse, A. Haug, A.S. Hennion, L. Lesobre, F. Marques \& R.O’Meara. 2001. Stratification and diel activity of arthropods in a lowland rainforest in Gabon. Biol. J. Linn. Soc. 72 : 585-607.

Basset, Y., V. Novotny, S.E. Miller \& R.L. Kitching. 2003. Arthropods of tropical forests-spatio-temporal dynamics and resource use in the canopy. Cambridge University, Cambridge, United Kingdom.

Bell, S.S., E.D. McCoy \& H.R. Mushinsky. 1991. Habitat Structure-The Physical Arrangement of Objects in Space. Chapman \& Hall, London, United Kingdom.

Bell, A.D., A. Bell \& T.D. Dines. 1999. Branch construction and bud defence status at the canopy surface of a West African rainforest. Biol. J. Linn. Soc. 66: 481-499.
Bernays, E.A. 1997. Feeding by lepidopteran larvae is dangerous. Ecol. Entomol. 22: 121-123.

Bernays, E.A. \& R.F. Chapman. 1994. Host-Plant Selection by Phytophagous Insects. Chapman \& Hall, New York, USA.

Borror, D.J., C.A. Triplehorn \& N.F. Johnson. 2002. An introduction to the study of insects. Saunders College, Orlando, Florida, USA.

Campos, R.I., H.L. Vasconcelos, S.P. Ribeiro, F.S. Neves \& J.P. Soares. 2006a. Relationship between tree size and insect assemblages associated with Anadenanthera macrocarpa. Ecography 29: 442-450.

Campos, R.I., J.P. Soares, R.P. Martins \& S.P. Ribeiro. 2006b. Effect of habitat structure on ant assemblages associated to two pioneer tree species (Hymenoptera: Formicidae). Sociobiology 47: 722-723.

Coley, P.D. \& J.A. Barone. 1996. Herbivory and plant defenses in tropical forests. Annu. Rev. Ecol. Syst. 27: 305-335.

Costa, V.C., F.S. Neves, J.O. Silva \& M. Fagundes. 2011. Relationship between plant development, tannin concentration and insects associated with Copaifera langsdorffii (Fabaceae). Arthropod-Plant Interac. 5: 9-18.

Crawley, M.J. 2002. Statistical computing-an introduction to data analysis using s-plus. John Wiley \& Sons, London, United Kingdom.

Denno, R.F. 1994. The influence of habitat structure on the abundance and diversity of planthoppers, p. 140-159. In R.F. Denno \& T.J. Perfect (eds.). Planthoppers: Their Ecology and Management. Chapman \& Hall, London, United Kingdom.

Denno, R.F. \& G.K. Roderick. 1991. Influence of patch size, vegetation texture, and host plant architecture on the diversity, abundance, and life history styles of sap-feeding herbivores, p. 169-196. In S.S. Bell, E.D. McCoy \& H.R. Mushinsky (eds.). Habitat Structure-The Physical Arrangement of Objects in Space. Chapman \& Hall, London, United Kingdom.

Denno, R.F. \& T.J. Perfect. 1994. Planthoppers: Their Ecology and Management. Chapman \& Hall, London, United Kingdom.

Espírito-Santo, M.M., F.S. Neves, F.A. Andrade-Neto \& G.W. Fernandes. 2007. Plant architecture and merystem dynamics as the mechanisms determining the diversity of gall-inducing insects. Oecologia 153: 353-364.

Gilhuis, J.P. 1986. Vegetation Survey of the Parque Florestal Estadual do Rio Doce, MG, Brasil. Master Tesis, Universidade Federal de Viçosa \& Wageningen Agricultural University, Viçosa, Brasil.

Godfray, H.C.J. \& J.H. Lawton. 2001. Scale and species numbers. Trends. Ecol. Evol. 16: 400-404. 
Hallé, F., R.A.A. Oldeman \& P.B. Tomlinson. 1978. Tropical Trees and Forests, an Architectural Analysis. Springer-Verlag, Berlin, Germany.

Heisswolf, A., E. Obermaier \& H.J. Poethke. 2005. Selection of large hosts plants for oviposition by a monophagous leaf beetle: nutritional quality or enemy-free space? Ecol. Entomol. 30: 299-306.

Hunter, M.D., G.C. Varley \& G.R. Gradwell. 1997. Estimating the relative roles of top-down and bottom-up forces on insect herbivore populations: a classic study revisited. P. Natl. Acad. Sci. Biol. 94: 9176-9181.

Kitching, R.L., H. Mitchell, G. Morse \& C. Thebaud. 1997. Determinants of species richness in assemblages of canopy arthropods in rainforests, p. 131-150. In N.E. Stork, J. Adis \& R.K. Didham (eds.). Canopy Arthropods. Chapman \& Hall, London, United Kingdom.

Lawton, J.H. 1983. Plant architecture and the diversity of phytophagous insects. Annu. Rev. Entomol. 28: 23-39.

Lewinsohn, T.M., V. Novotny \& Y. Basset. 2005. Insects on plants: diversity of herbivore assemblages revisited. Annu. Rev. Ecol. Syst. 36: 597-620.

Lowman, M.D. 2009. Canopy research in the twenty-first century: a review of arboreal ecology. Trop. Ecol. 50: $125-136$.

Lowman, M.D. \& N.M. Nadkarni. 1995. Forest Canopies. Academic, New York, USA.

Lowman, M.D. \& P.K. Wittman. 1996. Forest canopies: methods, hypotheses, and future directions. Annu. Rev. Ecol. Syst. 27: 55-81

Manly, B.F.J. 2005. Multivariate statistical methods: a primer. Chapman \& Hall, London, United Kingdom.

McCoy, E.D. \& S.S. Bell. 1991. Habitat structure: The evolution and diversification of a complex topic, p. 169-196. In S.S. Bell, E.D. McCoy \& H.R. Mushinsky (eds.). Habitat Structure-The Physical Arrangement of Objects in Space. Chapman \& Hall, London, United Kingdom.

Méis, M.R.M. \& A.M.F. Monteiro. 1979. Upper Quaternary "rampas": Doce river valley, Southeastern Brazilian plateau. Z. Geomorph. 23: 132-151.

Meis, M.R.M. \& J.G. Tundisi. 1986. Geomorphology and limnological processes as a basis for lake typology: the middle Rio Doce Valley Lake System. An. Acad. Bras. Ciênc. 58: 103-120.

Moran, C.V. \& T.R.E. Southwood. 1982. The guild composition of arthropod communities in trees. J. Trop. Ecol. 51: 289-306.

Myers, N., R.A. Mittermeier, C.G. Mittermeier, G.A.B. Fonseca \& J. Kent. 2000. Biodiversity hotspots for conservation priorities. Nature 403: 853-858.

Neves, F.S., L.S. Araújo, M.M. Espírito-Santo, M. Fagundes, G.W. Fernandes, G.A. Sanchez-Azofeifa \& M.
Quesada. 2010. Canopy herbivory and insect herbivore diversity in a dry forest-savana transition in Brazil. Biotropica 42: 112-118.

Nadkarni, N.M., G.G. Parker \& M.D. Lowman. 2011. Forest canopy studies as an emerging field of science. Ann. For. Sci. 68: 217-224.

Novotny, V., Y. Basset, S.E. Miller, G.D. Weiblen, B. Bremer, L. Cizek \& P. Drozd. 2002. Low host specificity of herbivorous insects in a tropical forest. Nature 416: 841-844.

Novotny, V., Y. Basset \& R. Kitching. 2003. Herbivore assemblages and their food resources, p. 40-53. In Y. Basset, V. Novotny, S. Miller \& R. Kitching (eds.). Arthropods of tropical forests: spatio-temporal dynamics and resource use in the canopy. Cambridge University, Cambridge, United Kingdom.

Ødegaard, F. 2003. Taxonomic composition and host specificity of phytophagous beetles in a dry forest in Panama, p. 220-236. In Y. Basset, V. Novotny, S. Miller \& R. Kitching (eds.). Arthropods of tropical forests: spatio-temporal dynamics and resource use in the canopy. Cambridge University, Cambridge, United Kingdom.

Overloop, E. 1981. Post-Glacial to Holocene transition in a peatlayer of lakes jacaré (Rio Doce Basin, Brazil). Bull. Societé Belge de Géologie 90: 107-119.

Peeters, P.J. 2002. Correlations between leaf structural traits and the density of herbivorous insect guilds. Biol. J. Linn. Soc. 77: 43-65.

Perônico, C. \& P.T. Castro. 2008. Análise faciológica e interpretação palinológica de testemunho recuperado de ambiente lacustre assoreado no Parque Estadual do Rio Doce (MG). Rev. Bras. Geociências 38: 654-660.

Pflug, R. 1969. Quaternary lakes of eastern brazil. Photogrammetria 24: 29-35

Rasband, W.S. 2006. Image J.U.S. National Institutes of Health, Bethesda, Maryland, USA. (Downloaded: November 15, 2006, http://rsb.info.nih.gov/ij).

Rehill, B. \& J. Schultz. 2002. Opposing survivorship and fecundity effects of host phenology on the gall-forming aphid Hormaphis hamamelidis. Ecol. Entomol. 27: 475-483.

Ribeiro, S.P. 2003. Insect herbivores in the canopies of savannas and rainforests, p. 348-359. In Y. Basset, V. Novotny, S. Miller \& R. Kitching (eds.). Arthropods of tropical forests: spatio-temporal dynamics and resource use in the canopy. Cambridge University, Cambridge, United Kingdom.

Ribeiro, S.P., M.B. Silva, M.C. Tagliati \& C. ChavanaBryant. 2011. Vegetation traits and herbivory distribution in an Australian subtropical forest. Memoir. Queensl. Mus. 55: 481-493.

Ribeiro, S.P., P.A.V. Borges, C. Gaspar, C. Melo, A.R.M. Serrano, J. Amaral, C. Aguiar, G. Andre \& J.A. 
Quartau. 2005. Canopy insect herbivores in the Azorean laurisilva forests: key host plant species in a highly generalist insect community. Ecography 28 : 315-330.

Ribeiro, S.P., J.P. Soares, R.I. Campos \& R.P. Martins. 2008. Insect herbivores species associated to pioneer tree species: contrasting within forest and ecotone canopy habitats. Rev. Bras. Zooc. 10: 141-152.

Ribeiro, S.P. \& Y. Basset. 2007. Gall-forming and free-feeding herbivory along vertical gradients in a lowland tropical rainforest: the importance of leaf sclerophy1ly. Ecography 30: 663-672.

Ribeiro, S.P. \& P.A.V. Borges. 2010. Canopy habitat area effect on the arthropod species densities in the Azores: pondering the contribution of tourist species and other life histories, p. 81-106. In R.M. Serrano, P.A.V. Borges, M. Boieiro \& P. Oromí (eds.). Terrestrial arthropods of Macaronesia - Biodiversity, Ecology and Evolution. Sociedade Portuguesa de Entomologia, Lisboa.

Rijhimäki, J., H. Vehviläinen, P. Kaitaniemi \& J. Koricheva. 2006. Host tree architecture mediates the effect of predators on herbivore survival. Ecol. Entomol. 31: $227-235$.

Rossi, A.M. \& P. Stiling. 1998. The interactions of plant clone and abiotic factors on a gall-making midge. Oecologia 116: 170-176.
Root, R.B. 1973. Organization of a plant-arthropod association in simple and diverse habitats: the fauna of collards (Brassica oleracea). Ecol. Monogr. 43: 95-124.

Sobek, S., I. Steffan-Dewenter, C. Scherber \& T. Tscharntke. 2009. Spatio temporal changes of beetle communities across a tree diversity gradient. Diversity Distrib. 15: 660-670.

Sterck, F.J., F. Bongers \& D.M. Newbery. 2001. Tree architecture in a Bornean lowland rain forest: intraspecific and interspecific patterns. Plant Ecol. 153: 279-292.

Stiling, P. \& D.C. Moon. 2005. Quality or quantity: the direct and indirect effects of host plants on herbivores and their natural enemies. Oecologia 142: 413-420.

Stork, N.E., J. Adis \& R.K. Didham. 1997. Canopy Arthropods. Chapman \& Hall, London, United Kingdom.

Werneck, F.P., G.C. Costa, G.R. Colli, D.E. Prado \& J.W. Sites. 2011. Revisiting the historical distribution of seasonally dry tropical forests: new insights based on palaeodistribution modelling and palynological evidence. Global Ecol. Biogeogr. 20: 272-288.

Vehviläinen, H., J. Koricheva \& K. Ruohomäki. 2007. Tree species diversity influences herbivore abundance and damage: meta-analysis of long-term forest experiments. Oecologia 152: 287-298.

Veloso, H.P., A.L.R. Rangel-Filho \& J.C. Lima. 1991. Classificação da Vegetação Brasileira, Adaptada a um Sistema Universal. IBGE, Rio de Janeiro, Brasil. 
